\title{
Developmental Aspects of Peritoneal Dialysis Kinetics in Dogs
}

\author{
ABDELAZIZ Y. ELZOUKI ${ }^{(29)}$ ALAN B. GRUSKIN, ${ }^{(29)}$ H. JORGE BALUARTE, MARTIN S. POLINSKY, \\ AND JAMES W. PREBIS \\ Section of Pediatrics Nephrology, Department of Pediatrics, St. Christopher's Hospital for Children and Temple \\ University School of Medicine, Philadelphia, Pennsylvania, USA, and Department of Pediatrics, Faculty of Medicine, \\ University of Garyounis, Benghazi, Libya
}

\begin{abstract}
Summary
To determine whether solute transfer during peritoneal dialysis is age related and to identify those factors which might explain age-related differences in dialysis kinetics, the peritoneal dialysance of $\left[{ }^{14} \mathrm{C}\right]$ urea $\left(\mathrm{D}_{U}\right),\left[{ }^{3} \mathrm{H}\right]$ inulin $\left(\mathrm{D}_{\mathrm{I}}\right)$, and the permeability index $\left(D_{R}=D_{I} / D_{U}\right)$ were examined in six puppies and five adult dogs. Exchange volume of lactated Ringer's $(40 \mathrm{ml} / \mathrm{kg})$ and exchange times $(30 \mathrm{~min})$ were identical in all studies. Theoretical calculations for urea dialysance for animals of differing body size were made. Assuming the existence of a similar functional peritoneal surface area per $\mathrm{kg}$ and the use of similar exchange volumes per $\mathrm{kg}$ and dwell times, theoretical values for the urea dialysance per kg for different sized animals were identical. The experimental studies demonstrated that $D_{I}$ per $\mathrm{kg}$ and $D_{U}$ per $\mathrm{kg}$ were higher in the puppies $(0.146 \pm 0.023$ and $0.765 \pm 0.054 \mathrm{ml} / \mathrm{min} / \mathrm{kg} ; \overline{\mathrm{X}} \pm$ S.E.) than in the adult $(0.052 \pm 0.01$ and $0.462 \pm 0.05 \mathrm{ml} / \mathrm{min} / \mathrm{kg})$ $(P<0.01)$. Also, $D_{\mathrm{R}}$ was higher in the puppies $(0.187 \pm 0.026)$, than in the adults $(0.11 \pm 0.015)(P<0.05)$. The greater values for $D_{I}$ and $D_{U}$ per $k g$ and $D_{R}$ in the young are best explained by the young having an increased peritoneal membrane permeability as well as an increase in functional peritoneal surface area relative to body weight. This increase in solute movement is independent of the dialysis mechanics used in an exchange and reflects agerelated differences in the intrinsic characteristics of the peritoneal membrane.
\end{abstract}

Recent technical advances have renewed interest in peritoneal dialysis (PD) as a form of treatment for uremia. Many pediatric nephrologists feel that compared to hemodialysis PD offers a number of advantages to children. PD is mechanically easier to perform than hemodialysis in infants and neonates and is felt to be a more suitable technique for home training than hemodialysis. Also, patients undergoing PD are less likely to develop the undesired complications of rapid fluid removal and the dialysis disequilibrium syndrome. The fact that PD is being used with increasing frequency suggests that a better understanding of the principles of solute movement involved in PD in the young is needed if children are to derive the maximum benefit from this modality of treatment.

The four major factors influencing the transperitoneal movement of solute are $(15,16)$ : (1) peritoneal surface area (PSA); (2) permeability of the peritoneal membrane; (3) dialysate flow rate (i.e., volume of dialysate used in an exchange and dwell time); and (4) peritoneal capillary blood flow. The available studies designed to systematically study such differences between infants and adults excluding those dealing with anatomical measurements of the peritoneal membrane have not in our opinion unequivocally demonstrated that the transperitoneal movement of solute is different in infants. The available kinetic data comparing PD in the young to the adult need to be reevaluated for three reasons. Firstly, the mechanics of the dialytic procedure, i.e., dialysis flow rate and dwell times, have not been maintained constant in some studies (2). Secondly, peritoneal clearances in the young have been compared to peritoneal clearances in adults reported by other investigators who have used different dialysis mechanics during the dialysis procedure (3). Thirdly, the available comparative studies have measured peritoneal clearances rather than peritoneal dialysance, a technique which permits a more quantitative estimate of the mass transfer of solute when comparative studies are desired $(9,23)$.

The present studies had two objectives: firstly, to determine whether solute transfer during PD is indeed age related and, secondly, to identify those factors which might explain age-related differences in dialysis kinetics in the event that solute transfer across the peritoneal membrane was found to be different in the young. To achieve these goals, the simultaneous measurement of the peritoneal dialysance of urea as $\left[{ }^{14} \mathrm{C}\right]$ urea and inulin as $\left[{ }^{3} \mathrm{H}\right]$ inulin was performed in an identical fashion in two groups of dogs, puppies, and adults. Before performing these studies, a set of theoretical calculations using the formula for dialysance was made in an attempt to better understand the relationship between solute movement across the peritoneal membrane and growth as reflected by changes in body weight, size of body fluid compartments, and peritoneal permeability.

MATERIALS AND METHODS

\section{ANIMAL STUDIES}

All animals were allowed free access to water and/or the breast until 2 to $3 \mathrm{hr}$ before study. Nine healthy mongrel puppies less than 1 month of age and nine adult dogs were anesthetized with Pentobarbital (12 mg/lb), which was administered intravenously, and an endotracheal tube was inserted and connected to a Harvard respirator. Anesthesia was maintained subsequently by a continuous slow drip infusion of Pentobarbital. Teflon indwelling catheters were placed in the femoral artery for the purpose of obtaining arterial blood samples and in the femoral vein to infuse $\left[{ }^{14} \mathrm{C}\right]$ urea and $\left[{ }^{3} \mathrm{H}\right]$ inulin. The animal was maintained in supine position under a heating lamp, and the abdomen was shaved and prepared with tincture of iodine. A small incision was made over the linea alba above the umbilicus, and blunt dissection was carried down until the parietal peritoneum was identified. A PD catheter (24) was introduced into the peritoneal cavity, and the tip of the catheter was directed toward the right pelvic gutter. The incision was closed with a purse string suture. A few exchanges of lactated Ringer were performed to check the patency and drainage characteristics of the peritoneal catheter. The last exchange $(40 \mathrm{ml} / \mathrm{kg})$ was left in the abdominal cavity for $50 \mathrm{~min}$ to help maintain catheter patency during which time loading and sustaining infusions of $\left[{ }^{14} \mathrm{C}\right]$ urea and $\left[{ }^{3} \mathrm{H}\right]$ inulin were begun $(25)$. The placement of two peritoneal catheters was required in some animals to obtain adequate drainage. Due to difficulties in obtaining adequate drainage (because of omentum blocking the side openings) in the initial 
few studies in the adult dogs when using a standard peritoneal catheter, a special silastic peritoneal catheter (26) was used in the remaining adult dogs. This catheter had a wider diameter, $18 \mathrm{~mm}$, and a larger side opening than the standard commercially available PD catheters.

For the preparation to be considered technically adequate, a single catheter had to be able to drain more than $85 \%$ of the infused dialysate fluid within $5 \mathrm{~min}$, and leakage around the dialysis catheter could not occur. Three puppies and four adult dogs were rejected because of an inadequate rate of drainage of infused dialysate. In no case was it necessary to discontinue an individual study once an isotope infusion was begun. As described below, rigidly controlled rates of drainage of dialysate are required when performing comparative dialysance studies. Body temperature and blood pressure remained constant throughout the study in both groups of animals.

Once the adequacy of the preparation was assured, priming doses of $\left[{ }^{14} \mathrm{C}\right]$ urea and $\left[{ }^{3} \mathrm{H}\right]$ inulin were given. The sustaining doses of both $\left[{ }^{14} \mathrm{C}\right]$ urea and $\left[{ }^{3} \mathrm{H}\right]$ inulin were given at a rate calculated to offset the deterioration of their plasma concentration due to the renal excretion and/or peritoneal clearance of these solutes.

Dialysis exchanges were carried out with lactated Ringer's solution to which heparin $(2$ units $/ \mathrm{ml})$ was added. Lactated Ringer's solution was chosen to eliminate the osmotic gradient that develops across the peritoneal membrane when commercially available solutions containing $1.5 \%$ glucose are used. The exchange volume used for each exchange was $40 \mathrm{mg} / \mathrm{kg}$. The inflow and dwell time was precisely controlled to $20 \mathrm{~min}$, drainage time was controlled to $10 \mathrm{~min}$. No abdominal pressure was applied during the drainage phase of the exchange. The dialysate, i.e., the last exchange preceding the infusion of isotope, was left in the peritoneal cavity for $50 \mathrm{~min}$ during which the priming and sustaining doses of $\left[{ }^{3} \mathrm{H}\right]$ inulin and $\left[{ }^{14} \mathrm{C}\right]$ urea had the opportunity to diffuse throughout most of the extracellular and intracellular compartments, respectively. This was done to ensure that the solute which moved into the fluid-filled peritoneal cavity would derive from the rapid exchange sites within the extra and intracellular compartments. The dialysate was then drained and discarded. Two sequential identical exchanges of $40 \mathrm{mg} / \mathrm{kg}$ were then performed in each animal. These exchanges were used to calculate dialysance. The volume of dialysate drained was measured in a graduated cylinder. At the midpoint of each dialysis exchange, $4 \mathrm{ml}$ of blood were removed and immediately centrifuged, and the plasma was separated. The erythrocytes were diluted in $2.5 \mathrm{cc}$ of sterile isotonic saline solution and returned to the animal to maintain a stable hematocrit.

Plasma or dialysis fluid $(1.0 \mathrm{cc})$ was added to $15 \mathrm{ml}$ of BioFluor (25) (liquid scintillation cocktail) in counting vials (25); disintegration per minute $(\mathrm{dpm})$ for all samples in a given study were counted sequentially. The activity of $\mathrm{C}_{14}$ as $\left[{ }^{14} \mathrm{C}\right]$ urea and $\mathrm{H}_{3}$ as $\left[{ }^{3} \mathrm{H}\right]$ inulin in $\mathrm{dpm}$ was determined simultaneously in a Searo Mark II liquid scintillation counter (27). Samples were counted for 100 $\min$.

The dialysance values for both the theoretical and experimental studies for $\left[{ }^{3} \mathrm{H}\right]$ inulin $\left(\mathrm{D}_{\mathrm{I}}\right)$ (molecular weight, 5200$)$ and $\left[{ }^{14} \mathrm{C}\right]$ urea $\left(D_{U}\right)$ (molecular weight, 60) were calculated for each exchange period according to a formula previously described (11)

$$
D=-\ln \frac{\left[\frac{1-S_{D}\left(V_{D}+V_{B}\right)}{S_{B} V_{B}}\right]}{T} \cdot \frac{V_{B} \cdot V_{D}}{V_{B}+V_{D}}
$$

where $\mathrm{D}=$ dialysance in $\mathrm{ml} / \mathrm{min} ; \mathrm{S}_{\mathrm{D}}=$ solute concentration in dialysate $(\mathrm{dPM}) ; \mathrm{S}_{\mathrm{B}}=$ solute concentration in blood $(\mathrm{dPM}) ; \mathrm{V}_{\mathrm{B}}$ $=$ assumed volume of distribution within the body of urea or inulin ( 60 and $20 \%$ of body weight, respectively); $V_{D}=$ volume of dialysate in $\mathrm{ml}$ returned at the completion of an exchange; $\mathrm{T}=$ time in minutes from initiation of inflow until the completion of drainage $(30 \mathrm{~min})$. A dialysate ratio $\left(D_{R}=\frac{D_{I}}{D_{U}}\right)$ was calculated for each exchange $(9,10)$.
Experimentally derived data were used to calculate $\mathrm{D}_{\mathrm{U}}, \mathrm{D}_{\mathrm{I}}$, and $\mathrm{D}_{\mathrm{R}}$ in the animals. The actual volume of dialysate drained in each exchange was within $\pm 4 \%$ of the infused volume of $40 \mathrm{cc} / \mathrm{kg}$. No difference in the percentage of volume infused, compared to that which drained, occurred between the infant and adult dogs. Although serum osmolality was not measured, the fact that the drainage volumes so closely approximated the volume of fluid infused into the peritoneal cavity suggests that net movement of water between the extracellular fluid compartment and peritoneal cavity due to osmotic differences did not occur. The fact that the activity of $\left[{ }^{14} \mathrm{C}\right]$ urea and $\left[{ }^{3} \mathrm{H}\right]$ inulin $(\mathrm{dPM})$ in sequential plasma samples did not change by more than $10 \%$ in any animal supports our assumptions concerning the level of glomerular filtration rate and volume of distribution of these solutes within the body. As will be discussed, an error of 15 to $20 \%$ in estimating the size of the compartment occupied by total body water has little measurable effect on experimentally derived values for dialysance. The unpaired Student test was used to analyze the data (20). A $P$ value of $<0.05$ was considered significant. Results are expressed as mean \pm S.E.

\section{THEORETICAL CALCULATIONS}

One set of theoretical values for $\mathrm{D}_{\mathrm{U}}$ was calculated assuming different dwell times, different dialysate to blood ratios of solute, different volumes of distribution of urea within the body, and a constant body weight of $3 \mathrm{~kg}$ (Table 1). To examine the influence of each factor on dialysance, the calculations were done based on the assumption that only one variable changed during an exchange. A second set of theoretical values was calculated with the objective of evaluating the relationship of varying body weight on dialysance assuming volumes of distribution of 60 and $20 \%$ for urea and inulin, respectively, and two different sets of dialysate to blood ratios (peritoneal permeability) for each solute (Fig. 1). The theoretically derived values for $D_{I}$ and $D_{U}$ were calculated as actual values, corrected for body weight, and expressed as $\mathrm{ml}$ / $\mathrm{min} / \mathrm{kg}$

\section{RESULTS}

The results of the theoretical calculations for dialysance are summarized in Table 1 and Figure 1 . Theoretical values for dialysance, $\mathrm{ml} / \mathrm{kg}$ body weight, for different sized animals using a similar $V_{D}$ per $\mathrm{kg}$ for a given equilibration ratios $\left(\mathrm{S}_{\mathrm{D}} / \mathrm{S}_{\mathrm{B}}\right)$ were identical assuming the functional PSA per $\mathrm{kg}$ was similar (Fig. 1). An estimated error of 5 to 10 liters in adult dogs or an error of 100 to $500 \mathrm{ml}$ in puppies in the volume of distribution of solute within the body $\left(V_{\mathrm{B}}\right)$ did not significantly alter the dialysance of either urea or inulin at equilibration ratios $\left(\mathrm{S}_{\mathrm{D}} / \mathrm{S}_{\mathrm{B}}\right)$ below 0.6 (Fig. 1). Changes in the peritoneal permeability of a given weight animal as reflected by changes in the $\mathrm{S}_{\mathrm{D}} / \mathrm{S}_{\mathrm{B}}$ ratio altered dialysance in a similar direction but not in direct proportion (Table 1). Changes in dialysis mechanics, dwell times, and/or dialysate volume markedly influenced dialysance (Table 1). The changes in dialysance

Table 1. Theoretical effect of altering one of various parameters on dialysance

\begin{tabular}{cccccccc}
$\begin{array}{c}\text { Body wt } \\
(\mathrm{kg})\end{array}$ & Time & $\mathrm{S}_{\mathrm{D}}{ }^{1}$ & $\mathrm{~S}_{\mathrm{B}}$ & $\mathrm{V}_{\mathrm{D}}$ & $\mathrm{V}_{\mathrm{B}}$ & $\begin{array}{c}\mathrm{D}_{\mathrm{U}} \\
(\mathrm{ml} / \mathrm{min})\end{array}$ & $\begin{array}{c}\mathrm{D}_{\mathrm{U}} \mathrm{kg} \\
\text { body wt } \\
(\mathrm{ml})^{\prime} \\
\mathrm{min})\end{array}$ \\
\hline 3 & 30 & 4 & 10 & 120 & 1800 & 2.09 & 0.695 \\
3 & $60^{2}$ & 4 & 10 & 120 & 1800 & 1.04 & 0.347 \\
3 & 30 & $2^{2}$ & 10 & 120 & 1800 & 0.90 & 0.30 \\
3 & 30 & 4 & $14^{2}$ & 120 & 1800 & 1.36 & 0.453 \\
3 & 30 & 4 & 10 & $240^{2}$ & 1800 & 4.26 & 1.42 \\
3 & 30 & 4 & 10 & 120 & $2100^{2}$ & 2.08 & 0.693 \\
\hline
\end{tabular}

' $\mathrm{S}_{\mathrm{D}}$ and $\mathrm{S}_{\mathrm{B}}$, solute concentration dialysate and blood; $\mathrm{V}_{\mathrm{D}}$ and $\mathrm{V}_{\mathrm{B}}, \mathrm{V}_{\mathrm{D}}$, dialysate volume, $\mathrm{V}_{\mathrm{B}}$, volume of distribution of urea ( $60 \%$ of body weight); $\mathrm{D}_{\mathrm{U}}$, dialysance urea.

${ }^{2}$ Parameter altered. 
Table 2. Individual data for puppies

\begin{tabular}{|c|c|c|c|c|c|c|c|c|c|}
\hline \multirow[b]{2}{*}{ Puppy } & \multirow{2}{*}{$\begin{array}{l}\text { Wt } \\
(\mathrm{kg})\end{array}$} & \multicolumn{3}{|c|}{ Urea } & \multicolumn{3}{|c|}{ Inulin } & \multirow{2}{*}{\multicolumn{2}{|c|}{$\begin{array}{l}\mathrm{D}_{\mathrm{K}} \\
\frac{\mathrm{D}_{\mathrm{I}}}{\mathrm{D}_{\mathrm{U}}}\end{array}$}} \\
\hline & & $\frac{\mathrm{S}_{\mathrm{D}}{ }^{1}}{\mathrm{~S}_{\mathrm{B}}}$ & $\begin{array}{c}\mathrm{D}_{\mathrm{U}} \\
(\mathrm{ml} / \mathrm{min})\end{array}$ & $\begin{array}{c}\text { Du }_{\text {u }} \text { per } \mathrm{kg} / \text { body } \\
\text { wt }\end{array}$ & $\frac{\mathrm{S}_{\mathrm{D}}}{\mathrm{S}_{\mathrm{B}}}$ & $\begin{array}{c}\mathrm{D}_{\mathrm{I}} \\
(\mathrm{ml} / \mathrm{min})\end{array}$ & $\begin{array}{c}\mathrm{D}_{\text {I }} \text { per } \mathrm{kg} \text { body } \\
\text { wt }\end{array}$ & & \\
\hline 1 & 2.3 & 0.41 & 1.81 & 0.79 & 0.13 & 0.48 & 0.21 & 0.27 & \\
\hline 4 & 3.15 & 0.43 & 2.63 & 0.83 & 0.13 & 0.66 & 0.21 & 0.25 & \\
\hline 5 & 2.8 & 0.40 & 2.15 & 0.77 & 0.20 & 0.43 & 0.16 & 0.20 & \\
\hline 7 & 3.0 & 0.30 & 1.52 & 0.51 & 0.05 & 0.23 & 0.08 & 0.15 & \\
\hline 8 & 1.8 & 0.43 & 1.43 & 0.794 & 0.08 & 0.19 & 0.11 & 0.13 & \\
\hline 9 & 1.98 & 0.46 & 1.18 & 0.9 & 0.08 & 0.22 & 0.11 & 0.12 & \\
\hline Mean \pm S.E. & & $0.405 \pm 0.023$ & & $0.765 \pm 0.054$ & $0.095 \pm 0.013$ & & $0.146 \pm 0.023$ & 0.187 & \pm 0.026 \\
\hline
\end{tabular}

${ }^{1} \mathrm{~S}_{\mathrm{D}}$ and $\mathrm{S}_{\mathrm{B}}$, solute concentration in dialysate and blood; $\mathrm{D}_{\mathrm{U}}$ and $\mathrm{D}_{\mathrm{I}}$, dialysance urea and inulin; $\mathrm{D}_{\mathrm{R}}$, dialysance ratio.

Table 3. Individual data for adults ${ }^{1}$

\begin{tabular}{|c|c|c|c|c|c|c|c|c|}
\hline \multirow[b]{2}{*}{ Adult dog } & \multirow{2}{*}{$\begin{array}{l}\text { Wt } \\
(\mathrm{kg})\end{array}$} & \multicolumn{3}{|c|}{ Urea } & \multicolumn{3}{|c|}{ Inulin } & \multirow{2}{*}{$\begin{array}{c}\mathrm{D}_{\mathrm{R}} \\
\frac{\mathrm{D}_{\mathrm{I}}}{\mathrm{D}_{\mathrm{U}}}\end{array}$} \\
\hline & & $\frac{\mathrm{S}_{\mathrm{D}}}{\mathrm{S}_{\mathrm{B}}}$ & $\begin{array}{c}\mathrm{D}_{U}(\mathrm{ml} / \\
\min )\end{array}$ & $\begin{array}{c}\mathrm{D}_{\mathrm{U}} \text { per kg body } \\
\text { wt }\end{array}$ & $\frac{\mathrm{S}_{\mathrm{D}}}{\mathrm{S}_{\mathrm{B}}}$ & $\begin{array}{c}\mathrm{D}_{\mathrm{I}}(\mathrm{ml} / \\
\min )\end{array}$ & $\mathrm{D}_{\mathrm{I}}$ per $\mathrm{kg}$ body wt & \\
\hline 11 & 19 & 0.32 & 9.71 & 0.51 & 0.06 & 1.65 & 0.09 & 0.17 \\
\hline 13 & 24 & 0.20 & 7.09 & 0.3 & 0.02 & 0.79 & 0.03 & 0.11 \\
\hline 14 & 22.5 & 0.29 & 10.08 & 0.45 & 0.03 & 0.81 & 0.04 & 0.08 \\
\hline 15 & 21.5 & 0.28 & 9.44 & 0.44 & 0.03 & 0.98 & 0.05 & 0.10 \\
\hline 16 & 20.68 & 0.30 & 12.67 & 0.61 & 0.04 & 1.13 & 0.05 & 0.09 \\
\hline Mean \pm S.E. & & $0.29 \pm 0.027$ & & $0.462 \pm 0.050$ & $0.036 \pm 0.007$ & & $0.052 \pm 0.010$ & $0.110 \pm 0.015$ \\
\hline
\end{tabular}

'See Table 2 legend for abbreviations.

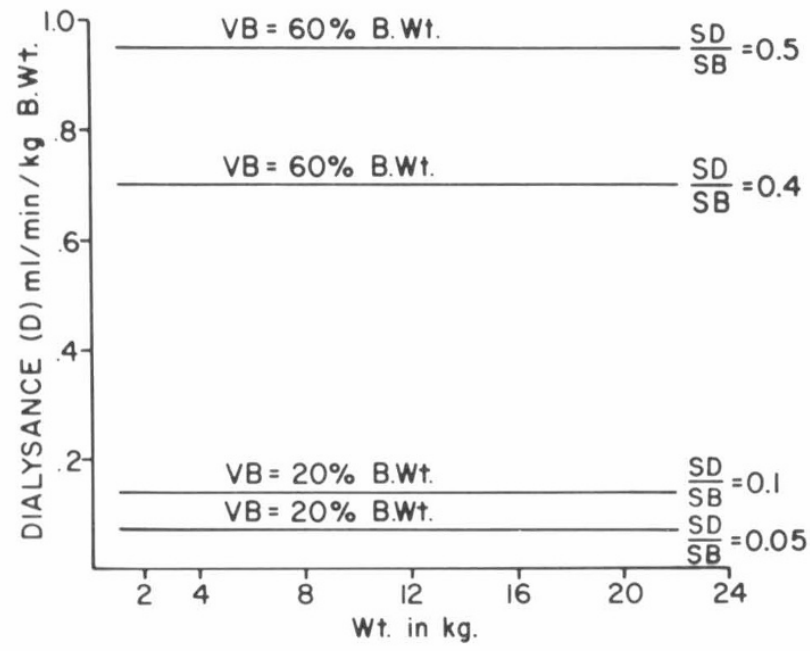

Fig. 1. Theoretical calculation of dialysance per $\mathrm{kg}$ for animals of varying weights. $V_{B}=$ different volumes of distribution within the body solute. The values of 20 and $60 \%$ of body weight represent the usually accepted exchangeable values of distribution for inulin and urea, respectively. The $\mathrm{S}_{\mathrm{D}} / \mathrm{S}_{\mathrm{B}}$ ratio represents generally acceptable values for the concentration ratios of inulin and urea obtained when dialysate has been left in the peritoneal cavity for $30 \mathrm{~min}$. The dialysance per $\mathrm{kg}$ is identical in animals of different weights when the volume of distribution of solute and $\mathrm{S}_{\mathrm{D}} / \mathrm{S}_{\mathrm{B}}$ ratio is similar.

associated with changes in $\mathrm{S}_{\mathrm{D}} / \mathrm{S}_{\mathrm{B}}$ ratio and/or dwell times were independent of body weight (Table 1).

The dialysance ratios and individual dialysance values for $\left[{ }^{3} \mathrm{H}\right]$ inulin and $\left[{ }^{14} \mathrm{C}\right]$ urea expressed as actual values and after correction for body size expressed in $\mathrm{ml} / \mathrm{min} / \mathrm{kg}$ for puppies and adult dogs are given in Tables 2 and $3 . \mathrm{D}_{\mathrm{U}}$ averaged $0.462 \pm 0.05$ $\mathrm{ml} / \mathrm{min} / \mathrm{kg}$ in adult dogs and $0.765 \pm 0.054 \mathrm{ml} / \mathrm{min} / \mathrm{kg}$ in the puppies $(P<0.003)$ (Fig. 2). $\mathrm{D}_{\mathrm{I}}$ in adults and puppies was 0.052 $\pm 0.01 \mathrm{ml} / \mathrm{min} / \mathrm{kg}$ and $0.146 \pm 0.023 \mathrm{ml} / \mathrm{min} / \mathrm{kg}$, respectively $(P$ $<0.006$ ) (Fig. 2). The $\mathrm{D}_{\mathrm{R}}$ in the adult dogs was $0.11 \pm 0.015$, and in the puppies, it was $0.187 \pm 0.026(P<0.04)$ (Fig. 3). Noteworthy is the observation that individual $\mathrm{S}_{\mathrm{D}} / \mathrm{S}_{\mathrm{B}}$ ratios for both $\left[{ }^{14} \mathrm{C}\right]$ urea

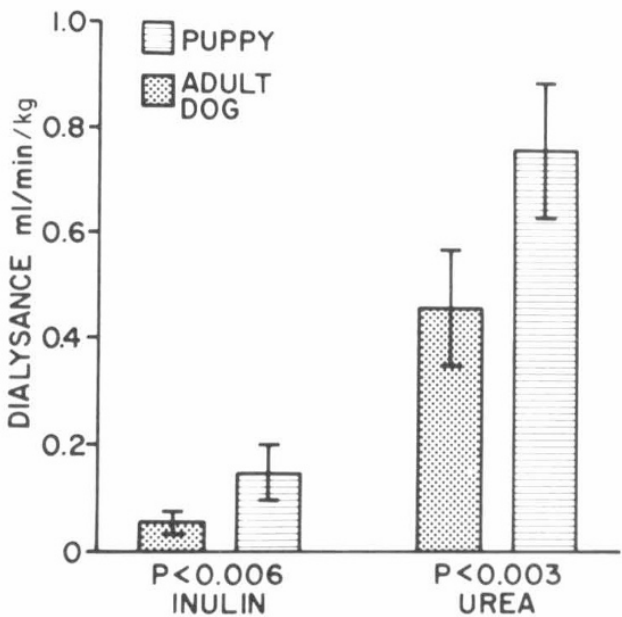

Fig. 2. Summary of experimentally obtained dialysance data in puppies and adult dogs. The dialysance of both urea and inulin was greater in the puppies.

and $\left[{ }^{3} \mathrm{H}\right]$ inulin in each puppy was higher, with the exception of puppy 7 , than in any adult dog.

\section{DISCUSSION}

Although it is commonly stated that PD is more efficient in the young than in the adult, the meaning of the term efficiency has not been clearly defined. The term efficiency has been used to imply that the following occurs when PD is performed in the young: more solute is removed during PD, solute movement across the peritoneal membrane occurs more rapidly, more water is removed, or the rate of decrease in blood urea nitrogen and/or creatinine is greater.

The published data dealing with the developmental aspects of PD suggest that the technique of PD may be a more efficient therapeutic modality in children than in adults because of agerelated differences in one or more of the following: (1) the anatomically measured surface area in children in relation to body 


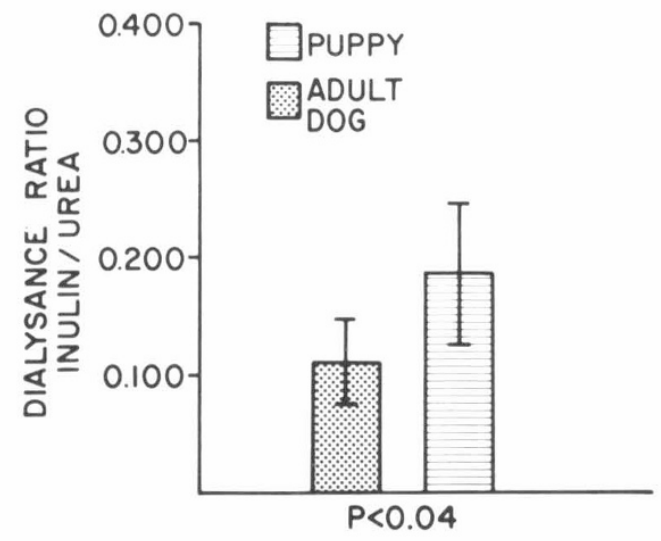

Fig. 3. Summary of experimentally derived dialysance ratio of inulin to urea in puppies and adult dogs. The dialysance ratio was greater in puppies.

weight is larger in children than in adults $(2,17)$; (2) the permeability characteristics of the peritoneal membrane are different in children than in adults (3); and (3) different dialysate flow rates, i.e., dialysis mechanics, in relation to body weight are used in children (6). The relationship of our findings to each of these factors known to influence transperitoneal solute movement will be considered individually after considering the implications of our theoretical calculations. Because of the complex formula used to measure dialysance and the multiple assumptions upon which dialysance studies are based, a review of the physiologic implications of the dialysance formula and the interpretation of dialysance values and dialysance ratios when comparative studies are performed is indicated (9).

\section{DIALYSANCE}

Peritoneal dialysance is defined as the rate of movement of solute across the peritoneal membrane per unit of concentration gradient or the peritoneal clearance of a solute at time zero of an exchange. Dialysance is felt to be a more meaningful expression of transperitoneal solute movement, especially when comparative studies are done, than the determination of peritoneal clearance.

Peritoneal clearance differs from dialysance in that it represents a mean clearance per exchange and does not take into account the changing concentration gradient occurring through an exchange between blood and dialysate. Also, clearance measurements are unable to accurately account for the changing portion of the peritoneal membrane in direct contact with dialysate during the inflow, dwell, and drain phases of an exchange. Because clearance measurements are often performed using solutions hypertonic to plasma, ultrafiltration occurs during the exchange. This results in additional solute and water being added to the dialysate and will alter the calculated peritoneal clearance.

To perform meaningful comparative studies using the technique of peritoneal dialysance, four conditions must be operative (9): (1) ultrafiltration should not occur; (2) the volume of distribution of solute throughout the body should remain constant; (3) dialysis mechanics, i.e. inflow, dwell, drain time, and volume of dialysate instilled into the peritoneal cavity should be identical in each study; and (4) the exchange process between blood and dialysate should not be rate limiting for the involved solute. The dialysance studies performed in these animals met these criteria.

The results generated by our theoretical calculations offer a number of insights into the process of age-related changes in the transperitoneal movement of solutes of differing molecular weights. The values for the dialysance of a given solute will vary greatly when dialysis mechanics, i.e., when either the dwell time or volume of dialysate, are varied from one dialysis exchange to another. These calculations demonstrate the necessity to rigidly control the three phases of an exchange, inflow, dwell, and outflow, as well as the volume of fluid used in an exchange when comparative studies are performed. When the total exchange time and its component segments are not maintained constant in comparative studies, there is an effect of time on the total amount of contact time between dialysis solution and exchange membrane influencing the amount of solute which will cross the peritoneal membrane. This will alter the $\mathrm{S}_{\mathrm{D}} / \mathrm{S}_{\mathrm{B}}$ ratio of a given solute and change the calculated dialysance. Contrary to such influences, changes in the volume of distribution of solute throughout the body have only a minimal effect on dialysance.

Previously published theoretical calculations for dialysance have not included values for individuals having a small body size. The theoretical calculations for dialysance performed during the design phase of these studies demonstrated that dialysance per unit of body weight is independent of body weight when the PSA and peritoneal permeability in relation to body size is assumed to be identical. Assuming that these two factors are operative, identical values for dialysance are obtained when the dialysate volume per $\mathrm{kg}$ and dwell times are similar in animals of differing size.

The failure to demonstrate identical values in animals of different ages for $\mathrm{D}_{\mathrm{I}}$ or $\mathrm{D}_{\mathrm{U}}$ under such circumstances can be explained only by the existence of differences in either the size of and/or the functional segment of PSA and/or peritoneal permeability (8-10). Examination of the formula for peritoneal permeability index

$$
\mathrm{D}_{\mathrm{R}}=\frac{\mathrm{D}_{\mathrm{I}}}{\mathrm{D}_{\mathrm{U}}}=\frac{\text { permeability inulin }}{\text { permeability urea }} \times \frac{\text { membrane area }}{\text { membrane area }}
$$

reveals that the membrane area for simultaneously determined pairs of dialysance is identical. The determination of $D_{R}$ provides a dimensionless index of permeability (8); therefore, changes observed in $\mathrm{D}_{\mathrm{R}}$ in comparatively performed studies can only be attributed to difference in peritoneal permeability (8).

\section{PERITONEAL MEMBRANE SURFACE AREA}

Two explanations may account for our finding that the $D_{U}$ per $\mathrm{kg}$ was higher in puppies that in adult dogs. Firstly, the puppies may have a larger functional PSA in relation to their body weight than do adults. The term functional is used here to represent only that portion of the peritoneal membrane which actually participates in the transperitoneal movement of solute. Secondly, the effective peritoneal capillary blood flow may be greater in the young. This factor will be considered later.

The finding of a larger functional peritoneal surface area may be explained by the occurrence in the young of one or more of the following: an increase in the anatomical area of peritoneal membrane with a concomitant increase in the total number of pores, an increase in the percentage of the peritoneal membrane in juxtaposition to the exchange membranes of the capillary, or an increase in the percentage of total pore area in relation to membrane area. There is evidence to suggest that the first factor best explains the finding of an increased $D_{U}$ per $\mathrm{kg}$ in the puppies. Two studies in which the PSA was actually measured in infants and adults $(2,17)$ have shown that the PSA relative to body size in newborns is approximately twice that of adults. Assuming the size, number, and configuration of pores to be similar in infants and adults, it would be expected that $\mathrm{D}_{\mathrm{U}}$ per $\mathrm{kg}$ in infants would be approximately twice that of adults. Our finding that $D_{U}$ per $\mathrm{kg}$ in infants was 1.66 times that of adults is compatible with this explanation when one considers that the puppies were not quite newly born; however, the finding that both $D_{I}$ per $k g$ and $D_{R}$ were greater in infants than adults suggests that an additional mechanism is simultaneously influencing the transperitoneal movement of solute in the young.

\section{PERITONEAL MEMBRANE PERMEABILITY}

Differences in $D_{R}$ between puppies and adult dogs can be explained only as reflecting differences in peritoneal membrane permeability $(8,9)$. Not only was $\mathrm{D}_{\text {I }}$ per $\mathrm{kg}$ higher in the puppies, but $\mathrm{D}_{\mathrm{I}}$ per $\mathrm{kg}$ was proportionately higher than $\mathrm{D}_{\mathrm{U}}$ per $\mathrm{kg}$, resulting in an increased $D_{R}$. Thus, the permeability of the peritoneal 
membrane to solute was greater in the puppies than in the adult dogs. A number of factors are known to alter peritoneal membrane permeability: the size of the pore, i.e. (pore radius); the relative proportion of mesenteric versus parietal peritoneum sharing the process of solute transfer (studies in dogs suggest that the visceral peritoneum is more permeable than the parietal peritoneum), (8); the size of the stagnant fluid layer on the endothelial and mesonthelial side may add to the total resistance to solute diffusion (15); the dynamic status of peritoneal microvasculature (1), vasodilation versus vasoconstriction could alter membrane permeability (7, 12); and the total path length that solute has to move across, i.e., the thickness of the membrane may affect permeability (5). Finally, peritoneal permeability increases when capillary perfusion pressure increases, "the stretched pore phenomena" (19). The permeability differences observed in these studies between infants and adults could be related to developmental differences in one or more of these factors. Further studies are indicated to define the degree to which age-related differences in these factors exist.

\section{DiALYSATE FLOW RATE (DIALYSATE VOLUME AND DWELL TIME)}

Our theoretical calculations demonstrate the well-known fact that changes in dialysate flow rate (QD) markedly influence peritoneal clearance and/or dialysance of solute $(20,22)$. The clearance of small solutes such as urea are more dependent on QD than the clearance of larger molecular weight solutes (16). It has been shown that the instillation of large volumes of dialysate into the peritoneal membrane will alter the $\mathrm{S}_{\mathrm{D}} / \mathrm{S}_{\mathrm{B}}$ ratio of solutes and influence peritoneal clearances $(4,18)$. Precise exchange volumes in relation to body weight, i.e., QD per $\mathrm{kg}$, times at which blood samples were obtained in relation to the exchange, and the possible use of a dialysis solution containing $7 \%$ glucose could not be ascertained from the available data in another study in which PD was felt to be more efficient in the young. The reasons for an increased urea clearance per $\mathrm{kg}$ in the young in these two studies can be explained on the basis of the use of different dialysis mechanics, i.e., QD per $\mathrm{kg}$ and dwell times, as well as on the basis of differences in the intrinsic characteristics of the peritoneal membrane $(2,3)$. The potential effect on dialysance of varying QD per $\mathrm{kg}$ and dwell time was avoided in these studies by using an identical QD per $\mathrm{kg}$ and dwell time in both puppies and adults. Consequently, a similar QD per $\mathrm{kg}$ was obtained in each study. We assumed similar volumes of distribution per $\mathrm{kg}$ for both urea $(60 \%)$ and inulin $(20 \%)$ in the puppies and adults. Although it is possible that the percentage of body water was somewhat higher in the younger puppies, the theoretical calculations demonstrate that such changes should not significantly affect the calculated dialysance.

When QD per kg and inflow, dwell, and outflow are maintained constant, any differences in the transperitoneal movement of solute must be reflected by changes in the $\mathrm{S}_{\mathrm{D}} / \mathrm{S}_{\mathrm{B}}$ ratio. The findings of a higher $\mathrm{S}_{\mathrm{D}} / \mathrm{S}_{\mathrm{B}}$ ratio for both $\left[{ }^{14} \mathrm{C}\right]$ urea and $\left[{ }^{3} \mathrm{H}\right]$ inulin in the puppies can be interpreted only as indicating that a greater transperitoneal movement of solute of both low and middle molecular weight solutes occurred in the young.

\section{PERITONEAL BLOOD FLOW}

No data are available on the subject of peritoneal blood flow in the young. It has been suggested $(8,14)$ that it is reasonable to assume that the peritoneal capillary blood flow in most circumstances is sufficiently great in normal adult animals so that it does not affect the transperitoneal movement of solute. Indeed, the dialysance formula assumes an infinite effective peritoneal capillary blood flow. Changes in peritoneal capillary blood flow, however, have been shown to influence solute exchange. Reductions and increases in peritoneal capillary blood by antidiuretic hormone (10) and by nitroprusside (7) have been suggested as the mechanism by which these agents influence solute exchange across the peritoneal membrane. Because $D_{U}$ per $\mathrm{kg}$ was increased in the puppies, it is obvious that urea transfer in the young was not significantly limited by capillary blood flow. Although it may be speculated that the decrease in $\mathrm{D}_{\mathrm{U}} / \mathrm{kg}$ with age reflects age-related decreases in peritoneal capillary blood flow, two observations argue against this suggestion. Firstly, blood flow to most organs except for the thymus remains stable or increases with age (13). Secondly, if this hypothesis is correct, it would be expected that the $D_{I} / D_{U}$ ratio would remain constant or increase with age. Because the $D_{1} / D_{v}$ ratio decreased with age in these studies, it would appear that age-related changes in solute movement across the peritoneal membrane cannot be explained by age-related alterations in peritoneal capillary blood flow.

\section{AN INTEGRATED CONCEPT OF THE DEVELOPMENTAL ASPECTS OF TRANSPERITONEAL SOLUTE MOVEMENT}

The increased $D_{U}$ per $\mathrm{kg}, \mathrm{D}_{\mathrm{I}}$ per $\mathrm{kg}$, and $\mathrm{D}_{\mathrm{R}}$ in the young obtained in these comparative studies can be best explained as resulting from a combination of increases in peritoneal membrane surface area and in peritoneal membrane permeability. Changes in the transperitoneal movement of urea by virtue of its being a low molecular weight solute with comparative high diffusability must reflect developmental alterations in the peritoneal membrane area, i.e., the number of available pores (8), whereas the combination of an increase in $D_{I}$ per $\mathrm{kg}$ and $\mathrm{D}_{\mathrm{R}}$ in the young indicate that the permeability of the peritoneal membrane is also increased in the young.

When efficiency of peritoneal dialysis is defined as a greater rate of solute movement across the peritoneal membrane, the efficiency of peritoneal dialysis is greater in the young than in the adults. This increase in efficiency is independent of dialysis mechanics. The observed differences in solute transfer in the young of both small and large molecular weight solutes has clinical implications. Insofar as urea generation per $\mathrm{kg}$ in uremic children is similar to that in adults, the efficiency of peritoneal dialysis as monitored by changes in blood urea nitrogen and/or creatinine will be greater in the young when similar dialysis mechanics are used. Peritoneal dialysis in the young when compared to the adult should also be more effective in removing middle molecular weight compounds. Manipulations of dialysis mechanics, dialysate volumes, and dwell times in the young will further augment any intrinsic differences in the transperitoneal movement of solute in the young.

In conclusion, these studies support previous suggestions that $\mathrm{PD}$ is more efficient in the young. If one adds previously available data to that obtained in these studies, the clinically observed increased efficiency of PD in the young may be concluded to derive from at least three factors: (1) the functional PSA is greater in the young; (2) peritoneal membrane permeability to small and middle weight molecular weight solutes is greater in the young, and (3) commonly used dialysis mechanics, especially QD per kg, in the young favor the removal of more solute per $\mathrm{kg}$.

\section{REFERENCES AND NOTES}

1. Corton, R. S.: The fine structure of the microvasculature in relation to normal and altered permeability. In: E. B. Reeve, A. C. Guyton: Physical Bases of Circulatory Transport. pp. 249-275 (W. B. Saunders Co., Philadelphia, 1967).

2. Esperance, M. J., and Collins, D. L.: Peritoneal dialysis efficiency in relation to body weight. J. Pediatr. Surg., 1: 162 (1966)

3. Feldman. W., Baliah. T., and Drummond, K. N.: Intermittent peritoneal dialysis in the management of chronic renal failure in children. Am. J. Dis. Child, I/6: 30 (1968).

4. Goldschmidt, Z. H. Pute, H. H. Katz, M. A., and Shear, L.: Effect of dialysate volume on peritoneal dialysis kinetics. Kidney Int., 5: 240 (1974).

5. Gosselin. R. E., and Berndt, W. O.: Diffusional transport of solutes through mesentry and peritoneum. J. Theor. Biol., 3: 487 (1962).

6. Gruskin, A. B., and Cote, M. L.: Kinetics of Peritoneal Dialysis in Children. Abstract of the Society for Pediatric Research. May 1970.

7. Harris, P., Pyle, K., and Popovich, R.: Effects of nitroprusside on peritoneal mass transfer coefficient and microvascular physiology. Trans. Am. Soc. Artif. Intern. Organs, 23: 210 (1977).

8. Henderson, L. W.: The problem of peritoneal membrane area and permeability. Kidney Int.. 3: 409 (1973).

9. Henderson, L. W.: Peritoneal dialysis. In: S. G. Massry. A. L. Sellers: Clinical Aspects of Uremia and Dialysis. Chap. 19. pp. 555-582 (Charles C Thomas. Springfield, IL, 1976).

10. Henderson. L. W., and Kintzel, J. E.: Influence of antidiuretic hormone on 
peritoneal membrane area and permeability. J. Clin. Invest.. 50: 2437 (1971).

II. Henderson, L. W., and Nolph, K. D.: Altered permeability of the peritoneal membrane after using hypertonic peritoneal dialysis fluid. J. Clin. Invest., 48: 922 (1969).

12. Miller, F. N., Nolph, K. D., Harris, P. D., Rubin, J., Wiegman, D. L., Joshua, I. G., Twardowski, Z. J., and Ghods, A. J.: Microvascular and clinical effects of altered peritoneal dialysis solutions. Kidney Int., 15: 630 (1979).

13. Naeye, R. L.: Development of systemic and pulmonary arteries from birth through early childhood. Biol. Neonat., 10: 8 (1966).

14. Nolph, K. D. Personal communication

15. Nolph, K. D., Ghods, A. J., Brown, P., Van Stone, J., Miller, F. B., Wiegmann, D. L., and Harris, P. D.: Factors affecting peritoneal dialysis efficiency. Dial. Transplant., 6: 52 (1977)

16. Nolph, K. D., Popovich, R. P., Ghods, A. J., and Twardowski, A.: Determinants of low clearances of small solutes during peritoneal dialysis. Kidney Int., 13: 117 (1978).

17. Putiloff, P. V.: Materials for the study of the laws of growth of the human body in relation to the surface areas of different systems; the trial on Russian subjects of planigraphic anatomy as a means for exact anthropometry-one of the problems of antropology. Report of Dr. P. V. Putiloff at the Meeting of the Siberian Branch of the Russian Geographic Society. October 29, 1884, OMSK. 1886.

18. Robson, M., Oreopoulos, D. G., Izatt, S., Ogilvie, R., Rapoport, A., and Deveber. G. A.: Influence of exchange volume and dialysate flow rate on solute clearance in peritoneal dialysis. Kidney Int., 14: 486 (1978).

19. Shirley, H. H., Wolfram, C. G., Wasserman, K., and Mayerson, H. S.: Capillary permeability to macromolecules: stretched pore phenomenon. Am. J. Physiol. 190: 189 (1957)

20. Stephen, R. L.. Atkin-Thor, E., and Kolff, W. J.: Recirculating peritoneal dialysis with subcutaneous catheter. Trans. Am. Soc. Artif. Intern. Organs, 22: 575 (1976).

21. Swinscow, T. D. V.: Statistics at Square One, Ed. 2, p. 33 (The British Medical Association, London, 1977).

22. Tenckhoff, H., Ward, G., and Boen, S. T.: The influence of dialysate volume and flow rate on peritoneal clearance. Proc. Europ. Dial. Transpl. Assoc., 2: 113 (1965).

23. Vaamonde, C. A.: Peritoneal dialysis today. Kidney, I0: 31 (1977).

24. Abbott Laboratories, Chicago, IL

25. Obtained from the New England Nuclear Corporation, Boston. MA

26. Obtained from Extracorporeal Medical Specialities, King of Prussia, PA.

27. Searo, Chicago, IL.

28. The authors wish to thank Dr. E. Mackowick, D. Han, R. Brook. and D. Batchler for their technical assistance and E. Morris for her typographical assistance.

29. Requests for reprints should be addressed to: A. Y. Elzouki, Department of Pediatrics, Faculty of Medicine, University of Garyounis, Benghazi. Libya, or Alan B. Gruskin, M.D., St. Christopher's Hospital for Children, 5th and Lehigh Avenue, Philadelphia, PA 19133 (USA).

30. This research was supported in part by NIH Grant HL 23511-0I, General Clinical Research Center Grant RR-75, and in part by the Ministry of Education, Libya.

31. Received for publication June 18, 1980

32. Accepted for publication September 10, 1980. 